\title{
Like an Invertebrate Primitive Antibody
}

\author{
Michel Leclerc \\ 556 Rue Isabelle Romée 45640 Sandillon, France
}

Received 2013-07-18, Revised 2013-08-19; Accepted 2013-08-20

\begin{abstract}
Specific immune responses occur in an invertebrate: The sea star Asterias rubens. Sea star T and B lymphocytes are present in the axial organ and coopere with phagocytes and Complement components to produce a primitive antibody correlated to Igkappa genes and to complement genes: It could be composed of 4 kappa chains and present strong and highly significant homologies to Mouse IgKappa region V-IV S107B precursor gene.
\end{abstract}

Keywords: Invertebrate, Asterias, Phagocytes, IgKappa

\section{INTRODUCTION}

Numerous immunological works ended in the absence of antibody to Invertebrates (Bang, 1962) To day the works of Leclerc suggest another idea about this probem. Let us place particularly our experimental material (a) the sea star axial organ: we have been the first to describe it like a primitive ancestral lymphoïd organ (Leclerc et al., 1980) (b) Echinoderma in the biological evolution field (Echinoderma belonging to Invertebrates). Echinoderma are Deuterostomia and more likely to have been the ancestors of the Vertebrates than the Annelids. For more than 45 years our theme of researches was the study and more exactly the rôle of the axial organ, in the immune reactions of Asterids: these composing one of five classes of Echinoderma (c) Recently, we have used a particular immunological method: We have compared genomes of immunized and non-immunized sea star.

\section{RESULTS}

We have described, for the first time:

- Lymphocytes in Invertebrates: besides Sea star T and B lymphocytes (Anteunis et al., 1985)

- Cell-mediated immune responses and interactions with mammal lymphocytes, with target mammal cells such as cancerous mammal cells

- Humoral immune specific responses with primitive antibody production (Delmotte et al., 1986)

SMART_956.ab1:

tGACTGCTGCTATGCGTGGCAACATGGCGTCTCTATGGATGTTCTTCTTTGTCgTGGGGAT AACTTTACAACGGAGTTTGGCGATTTACACGTTTCGCGAGCAACCGTCGGACACTAGCG CGTTGCAGGGGAGCACAGTGGTGCTTCACTGCTCCGTTGAGCAGTACATAAACACCACG GCCATCGTTTGGTGGAGCCGTGACTCGGTCATCAGCCACAACAAAGACCTGAAACTGTC CAGTCTAAACACCGACCAGCTCCAAAGGTACTCGATTTCAGGCGACGCATCTCGGGGGG AATTCAACCTTAAAATAGTGAACTTTACCGNCACAGACGCCGCCAGTTACCGCTGTCAG ATGTTTGCGA

Fig. 1. DNA Sequence of sea star IgKappa gene 
It is on this last point that we are going to return because this specific immune reaction is correlated : (1) to IGKAPPA GENES (Leclerc and Dupont, 2011) (2) to COMPLEMENT GENES (Leclerc et al., 2013). From the point of view of the evolution of antibodies, through the animal kingdom, it is particularly difficult to place the appearance of genes kappa to Asterids and not to Echinids (another class of Echinoderma), in the Invertebrate world in a general way. This primitive antibody could play a rôle in Immunotherapy and Cancerology. Our ambition is to isolate this sea star Ig kappa gene in immunized sea star. Here is, in Fig. 1, the obtained gene according to.

\section{CONCLUSION}

The origin of lymphocytes, of primitive antibody, of complement, must be observed in Invertebrates and more particularly, in Asterids which have a «bright avenir »in the field of Comparative Immunology and could have also a fundamental rôle in immunotherapy.

\section{REFERENCES}

Anteunis, A., Leclerc,. M. Leclerc, M. Vial, C. Brillouet and G. Luquet et al., 1985. Immunocompetent cells in the starfish Asterias rubens. An ultrastructural study. Cell Biol. Int. Reports, 9: 663-670. DOI: 10.1016/0309-1651(85)90059-1
Bang, F.B.N., 1962. Serological aspects of immunity in invertebrates. Nature, Lett., 196: 88-89. DOI: 10.1038/196088a0

Delmotte, F., C. Brillouet, M. Leclerc and K. JeanClaude, 1986. Purification of an antibody-like protein from the sea star Asterias rubens (L.). Eur. J. Immun., 16: 1325-1330. DOI : 10.1002/eji.1830161103

Leclerc, M. and S. Dupont, 2011. Evidence of Kappa genes in the sea-star Asterias rubens (Echinoderma). Immun. Lett., 138: 197-198. DOI: 10.1016/j.imlet.2011.01.016

Leclerc, M., C. Brillouet and G. Luquet, 1980. The starfish axial organ: An ancestral lymphoid organ. Develop. Comparative Immunol., 4 : 605-615. DOI: 10.1016/S0145-305X(80)80063-2

Leclerc, M., N. Kresdorn and B. Rotterb, 2013. Evidence of complement genes in the sea-star Asterias rubens. Comparisons with the sea urchin. Immun. Lett., 151: 68-70. DOI: 10.1016/j.imlet.2013.02.003 